\title{
最新のゲノム解析から探る 和牛肉質のルーツ
}

河野友宏

\section{1. はじめに}

我が国で生産されている家畜・家禽の中で最 も付加価值の高い和牛（Wagyu）は、貴重な 遺伝的資源である。和牛は西洋種と日本在来牛 の交配と選抜を経て、昭和初期にその形質が確 立したとされ、現在、黒毛和種、無角和種、褐 色和種ならびに日本短角種の 4 品種が飼養され ている。中でも黒毛和種は和牛全体の $90 \%$ を 占めており、脂肪交雑（霜降り肉）の特性を有 する優れたウシとして世界に知られている。

この脂肪交雑の特性は、黒毛和種成立の過 程で交配に拘った日本在来牛の遺伝形質に由 来している可能性がある。そもそも牛は渡来人 により日本に導入されて、農耕や人・物資の運 搬などに役畜として利用され、各地に広がり定 着して在来牛となったと考えられる。しかし、 現在、西洋種の遺伝的影響を受けていない日本 在来牛は、鹿児島県トカラ列島の「口之島」に 生息する口之島牛と山口県萩市の離島「見島」 で飼育されている見島牛の 2 品種を残すだけと

なっている（図1）。そこで、遺伝子資源とし ても貴重な存在となった口之島牛と見島牛の 全ゲノム約 29 億塩基を、次世代シークエンサー を用いて解読し、西洋種（ヘレフォード種）の ゲノム配列と比較解析を実施した。この解析に より、口之島牛と見島牛の遺伝的特徵の全容が はじめて明らかとなった。

\section{2. 和牛品種の成立}

3世紀末に陳寿が著した中国の歴史書『三国 志』中の「魏志倭人伝」によれば、当時、日本 には牛馬がいなかったと記されている。一方、 我が国最古の正史『日本書紀』の「雄略 2 年（西 暦458年) 10 月の条」には、宍人部（ししひとべ： 食肉に携わる職の家系）の起源伝承として、生 肉を食べることは神事として記されている。こ のことから、古墳時代後半（6世紀）には牛が 飼育されていたものと思われる。ただし、我が 国においては長い間、牛は主に役牛として利用 されており、本格的に肉牛の育種・繁殖が行わ れるようになったのは明治

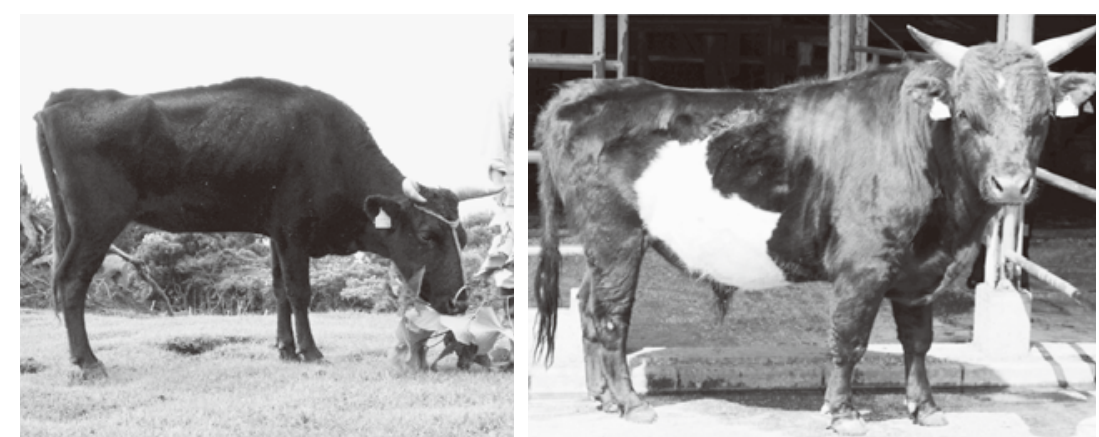

図 1 . 日本固有の在来牛 : 見島牛・雌（左）、口之島牛・雄（右）
に入ってからである。すな わち、明治以降、欧米の食 文化が持ち込まれる中で、 食肉の習慣が徐々に定着す るようになったことが、牛 の改良を後押しした。

日本で飼育されていた在 
来牛は、小型で発育も遅く、肉牛としての産肉 性は劣っていたのは確かである。そこで、在来 牛の改良のため西洋種との交配が行われた。当 時、各地で飼育されていた在来牛は、デヴォン 種、ブラウンスイス種、シンメンタール種、ア バディーン・アンガス種などの西洋種と交配さ れ、大型で増体の優れた牛への改良が試みられ たのであろう。明治36年に出版された図説に は、但馬種や出雲種が、西洋種とともに登場し ている。結局、現在の和牛 4 品種が造成され、 黒毛和種、無角和種および褐色和種は1944年 に、日本短角種は1957年に品種登録された。

その一方で、現存する在来牛は口之島牛と見 島牛のみである。口之島牛は、もともと明治以 前から放逐されていたものが野生化し、品種改 良を経ずに今日に至っており、西洋種の遺伝的 な影響を受けていない日本在来牛である。小柄 で後駆のしまった体格の特徵は、日本古来の牛 の形質を現在まで保持していると考えられ、国 宝「平時物語絵巻（六波羅行幸巻）」に登場す る牛車を引く牛とよく似ている。一方、見島牛 は農耕用として離島で飼育されていたことか ら、明治以前から今日まで品種間交雑が行われ て扮らず、口之島牛同様、西洋種の遺伝的な影 響を受けていない日本在来牛である。見島牛は 1928年に特別天然記念物に指定されている。 両品種とも体重は雄で $400 \mathrm{~kg}$ 、雌では300 kg と小型である。

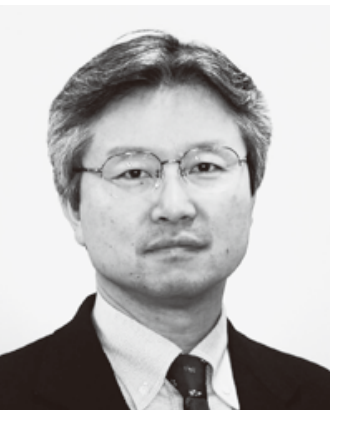

\section{PROFILE}

河野友宏

(こうの ともひろ)

東京農業大学応用生物科学部教授、

東京農業大学常務理事

専門: 繁殖生物学、発生工学、エピ ジェネテクス

\section{3. 全ゲノム解読の概要}

次世代シーケンサーは、超高速で虐大な塩基配 列決定を行う能力を発揮する。ここではIllumina 社のGenome Analyzer IIおよびHiSeq2000を用 いて解析を実施した。HiSeq2000では、100 bp 長の塩基配列の解読が可能で、1ランで約 600 $\mathrm{Gb}$ の塩基配列を決定する。これに要する日数 はわずか 8 日間である。牛のゲノムサイズは 2.9 $\mathrm{Gb}$ であるから、約 200 頭の塩基配列に相当す る。解析対象とした牛は、名古屋大学信楽牧 場で飼育されていた口之島牛雄 1 頭および山口 県萩市見島で飼育されていた見島牛雌 8 頭であ る。これらの牛の血液から DNAサンプルを調 整し、全ゲノム配列を決定した。

口之島牛では約 80 億リード（塩基配列決定 DNA断片）で合計 $64.2 \mathrm{~Gb}$ の塩基情報を取得 した。塩基配列を取得できたリードを既存の ゲノム配列に貼り付けるマッピングプログラ ムのBurrows-Wheeler Alignment（BWA）を 用いてヘレフォード種のゲノム配列 (genome database; bosTau6.0）に、ロ之島牛のリード をマッピングしたところ、 $89 \%$ のリードが張 
り付きゲノム全体の $95 \%$ をガ゙ーした。比較 解析の結果、29億塩基ある牛の全ゲノム中 に、 $723 \times 10^{4}$ 個の一塩基置換（Single Nucleotide Polymorphism, SNP) を発見し、そのうちの 87\%が新規のSNPであった。さらに、アミノ酸 置換を伴う非同義一塩基置換（non-synonymous, nsSNP）を20,053個同定し、それらが7,104遺伝 子に位置していることを明らかにした。

一方、現在 90 頭あまりと飼育頭数が減少し ている見島牛では、これまでの交配履歴に配慮 して8頭を選びゲノム解析を実施し、1頭あた り平均 2.07 億リード（20.6 Gb）を解読した。 BWA マッピングプログラムによって取得リー ドの $86 \%$ がゲノム配列情報（genome database; bosTau6.0）にマッピングされた。8頭の見島 牛ゲノムから平均 $733 \times 10^{4}$ 個のSNPを特定し た。塩基置換率は平均 $0.28 \%$ であった。さら に、それらのうちアミノ酸置換を伴うnsSNP は27,723個であることが判明した。見島牛に固 有なnsSNPを特定するため、口之島牛と共通 するnsSNPを除外した。その結果、見島牛に 固有な 452 個の nsSNP と、それらを保有する 331 遺伝子を突き止めた。加えて、見島牛8個 体間で比較を行ったところ、個体間の塩基置換 率は平均 $0.12 \%$ 、1 個体につき平均 $308 \times 10^{4}$ 個 のSNPを保持していることがわかった。当初 の予想を超えるSNPが見島牛の個体間に存在 しており、遺伝的多様性を保持していることが わかった。今後、適切な繁殖計画を立案するこ とにより、個体群における近交係数の上昇を避
け、貴重な在来牛の安定的な飼育繁殖に結びつ くことが期待される。

口之島牛および見島牛の牛属における系統 的な位置を確認するために、過去の報告で用 いられている10遺伝子の部分塩基配列（合計 21,865塩基）を用いて系統樹を作成したところ、 日本在来牛は明らかに西洋種（ヘレホード種、 ホルスタイン種）と独立して位置づけられた。 さらに、見島牛 8 頭は 1 集団を形成し、口之島 牛とは区別された。塩基置換率を見ると、見島 牛群内は $0.12 \%$ 、見島牛と口之島牛間は $0.16 \%$ であるのに対し、見島牛と西洋種間では $0.22 \%$ にまで拡大した。このことから、2品種の在来 牛は、明確に西洋種の牛集団から遺伝的に独立 していることが裏付けられた。

\section{4. 黒毛和種肉質のルーツ}

見島牛の最大の特徴は、筋肉繊維間に脂肪 交雑を生じる「霜降り肉」の形質を持つことに ある。したがって、黒毛和種が品種として造成 される過程で見島牛が保有する遺伝子が関与 している可能性も否定できない。我々の解析 で得られたnsSNPのうち、口之島牛のSNP と 共通するものを取り除いた結果、見島牛に固有 の nsSNPと、それらを保有する遺伝子を突き 止めた。したがって、これら遺伝子の中には、 見島牛が持つ「霜降り肉」を特徵付ける遺伝子 が含まれている可能性がある。たとえば肉質に 関係すると考えられる遺伝子機能情報をから、 
経済形質に関連する 4 遺伝子を染色体 $3 、 4 、 7 、$ 19 番上に見出すことができた。今後さらに詳細 な検証を加えることにより、重要な形質と関連 する遺伝子の特定に役立つことを期待したい。

（社）畜産技術協会の動物遺伝学研究所の研 究グループは、これまでに父方半きょうだい 家系を用いて、黒毛和種牛の量的形質や遺伝 病について研究を展開している。脂肪交雑に 関与する遺伝子領域については、7番染色体上 の約 4.6 Mb の Marbling-2（脂肪交雑 QTL）領 域を特定している。さらに、次世代シーケンサー を用いた網羅的SNP探索が行われ、Marbling-2 領域に責任 SNP 候補として1624個のSNPが特 定された。このうち、コーディング領域に位置 するものが19個のSNPsで、5個の nsSNPが含 まれている。今後の解析の進展による成果が期 待される。今後、見島牛の特有の nsSNPの情報 との関連性を解析することで、和牛肉質のルー ツに繋がる有益な情報の取得に繋がる可能性が ある。

\section{5. おわりに}

本研究で得られた成果は、口之島牛および見 島牛が我が国の在来牛として遺伝的な独立性 を堅持しながら保存されていることを証明し た。これら 2 品種の在来牛は、多様な遺伝子資 源を担保する意義からも、その重要性が確固た るものになった。また、和牛における経済的に 重要な形質や疾病に関与する遺伝的原因を追
究する上で、必要なゲノム情報を提供できたも のと考えている。事実、現在の繁殖様式が原因 となる遺伝的偏りによって、黒毛和種の遺伝的 多様性の減少が危惧されている。多様性の減少 は抗病性の低下や近交退化という事態に結び つくことが懸念される。今後、黒毛和種のゲノ ムの解読と、在来牛を含む他の品種とのゲノム レベルでの比較研究により、和牛の遺伝的多様 性を確保する道筋が開かれることを期待した い。何れにしても、我が国固有の貴重な在来牛 である口之島牛と見島牛が、その貴重な遺伝的 形質を保存しながら永く繁殖し続けることを 願って止まない。

\section{付記}

見島牛ゲノム解析については山口県萩市お よび見島ウシ保存会の多大な協力のもと実施 された。また、特別天然記念物である見島牛か らのサンプル (血液) の採取および研究の推進 には文化庁の許可を得て実施した。山口県萩市 の関係者各位および見島牛保存会の皆様の献 身的な保存活動に対し敬意を表したい。なお、 口之島牛ゲノム解析の研究成果は2011年に科 学雑誌BMC genomicsに掲載され、見島牛の研 究成果は現在投稿中である。詳細なゲノム情報 も近々公開することを予定している。 